\title{
DIGITALIZAÇÃO DE FILMES RADIOGRÁFICOS UTILIZANDO COSTURA DE IMAGENS
}

\author{
Digitalization of X-Ray Films Using Image Stitching
}

Jaime Grande Vela'; Amit Bhaya²

Resumo Esta dissertação propõe um método de digitalização de filmes radiográficos que utiliza um scanner de transparências convencional de baixo custo (scanner de mesa A4) e de um software de costura de imagens especialmente desenvolvido neste projeto. Este sistema faz aquisições parciais da imagem radiográfica, devido à diferença de tamanho entre o formato A4 (tamanho da área de digitalização do scanner de mesa) e o tamanho normal de um filme radiográfico. Dependendo do tamanho, um filme é escaneado duas ou quatro vezes. Com o intuito de juntar as partes da imagem digitalizada, desenvolveu-se um software que reconhece as partes da imagem armazenadas em arquivos de entrada temporários do sistema. Em seguida, por intermédio de um algoritmo de costura, fusionam-se as partes e a imagem digitalizada completa retorna como arquivo de saída. Este processo de costura venceu desafios como a não uniformidade do brilho nas imagens parciais, inclinação das imagens no momento de serem escaneadas e erros humanos no momento da aquisição parcial por parte do usuário.

Palavras-chave: Digitalização de radiografias, Costura de imagens, Imagens radiográficas.

Abstract This dissertation describes the technical and algorithmic details of a fast low cost method for the digitalization of X-ray films of allstandard sizes. In order to keep costs low, a standard A4 size flatbed scanner with transparency media adapter was used. Since most X-ray films are larger than the A4 size image capturing area of the scanner, it was necessary to develop an image processing algorithm that could stitch two or four partial images of the whole X-ray film, depending on its size, into a seamless full image of the film. Another important feature of the algorithm is that it automatically detects and corrects the most common user error of slightly tilted partial images and produces a warning message if the tilt is large enough that it may affect the quality of the stitched image. Similarly, non-uniformity of the brightness in the partial images is also compensated for in the stitching process. The proposed image stitching algorithm produces high resolution seamless images with good contrast and quality that permits their use in a tele-radiology project, which is the final goal.

Keywords: Digitalization of X-ray films, Stitching images, Radiographic images. 
O método de digitalização de filmes radiográficos proposto utiliza um scanner de transparências convencional de baixo custo (scanner de mesa A4) e um software de costura de imagens. Este sistema faz uma aquisição parcial da imagem radiográfica, devido à diferença de tamanho entre o formato A4 (tamanho da área de digitalização do scanner de mesa) e o tamanho médio de um filme radiográfico.

Para poder juntar as partes da imagem digitalizada, desenvolveu-se um software que reconhece as partes ou arquivos de entrada do sistema e um pré-processamento costura as partes, retornando como arquivo de saída a imagem digitalizada completa.

Este processo de costura enfrentou desafios como a não uniformidade do brilho nas imagens parciais, incli- nação das imagens no momentode serem escaneadas e erros humanos no momento da aquisição parcial por parte do usuário.

O resultado final deste sistema foi apresentado periodicamente aos integrantes do projeto TIPIRX (Teleintegração para Imagens em RX), composto por especialistas em Radiologia do setor de Radiologia do Hospital Universitário Pedro Ernesto, da UERJ, do serviço de Radiologia do Hospital Universitário Antônio Pedro da Universidade Federal Fluminense, do Serviço de Radiologia do Hospital Universitário Clementino Fraga Filho da Universidade Federal do Rio de Janeiro, assim como por representantes do Núcleo de Atendimento em Computação de Alto Desempenho NACAD/COPPE. 